\title{
Carcass characteristics and pork quality of pigs fed diets containing crude glycerin and ractopamine
}

\author{
Imara Guimarães Lima BARROS ${ }^{1}$, Cesar Augusto Pospissil GARBOSSA ${ }^{2}$, \\ Tatiane Mendonça Nogueira Carneiro de ALBUQUERQUE ${ }^{1}$, Claudiana Esteves COUTO ${ }^{1}$, \\ Sudário Roberto SILVA JUNIOR ${ }^{3}$, Adriana Brasil Ferreira PINTO ${ }^{1}$, \\ Peter Bitencourt FARIA ${ }^{1 *}$ (D), Luciana de Paula NAVES ${ }^{3}$
}

\begin{abstract}
An experiment was conducted to evaluate the effects of increasing concentrations of crude glycerin, with or without ractopamine, in the diet of finishing barrows on carcass characteristics and pork quality. The experimental design was a randomized complete block, in a 4 × 2 factorial scheme, with four concentrations of crude glycerin $(0,100,150$, or $200 \mathrm{~g} / \mathrm{kg})$ and two concentrations of ractopamine $(0$ or $10 \mathrm{mg} / \mathrm{kg})$. There was no interaction between the crude glycerin concentrations and the ractopamine use as well as there was no isolated effect of the dietary crude glycerin concentration for all the evaluated traits. However, the dietary ractopamine increased the hot $(\mathrm{p}=0.021)$ and cold $(\mathrm{p}=0.020)$ carcass weight, the hot carcass yield $(\mathrm{p}=0.038)$, the shear force $(\mathrm{p}=<0.0001)$, lightness $\left(\mathrm{L}^{*}\right.$ index $)(\mathrm{p}=0.043)$, hue angle $\left(\mathrm{h}^{*}\right)(\mathrm{p}=0.026)$, and C16:1 $(\mathrm{p}=0.023)$ concentration in the loin. Moreover, the dietary ractopamine decreased the red content ( $a^{*}$ value $)(p=0.043)$, the activity of C16-C18 elongase $(\mathrm{p}=0.037)$ and the C18:0 ( $\mathrm{p}=0.021)$ concentration in the loin. The inclusion of up to $200 \mathrm{~g} / \mathrm{kg}$ crude glycerin in the diet of finishing pigs may be used as a partial substitute for dietary corn, combined or not with $10 \mathrm{mg} / \mathrm{kg}$ ractopamine, without impair the evaluated carcass characteristics and the quality of the loin.
\end{abstract}

Keywords: $ß$-adrenergic agonist, biodiesel, coproduct, fatty acid profile, nutrition, swine.

Practical Application: The inclusion of crude glycerin with ractopamine on swine production does not compromise the meat quality.

\section{Introduction}

The main energy source in pig diets is corn. However, in addition to its use in human and animal diets, corn is used in various industrial processes, this contributes to an increase in its price, especially in times of lesser production. It is also important to emphasize that corn prices oscillate greatly in the national and international markets because it is a commodity. Thus, alternative sources of energy are pursued in animal diets to achieve optimal meat production.

Brazil is one of the largest producers and consumers of biodiesel in the world, and crude glycerin is a byproduct of biodiesel production. As the production of this biofuel has been increasing in recent years, the supply of crude glycerin in the market has also increased. In 2018, 5.3 billion liters of biodiesel and, consequently, 530 million liters of crude glycerin were produced in Brazil (Agência Nacional do Petróleo, Gás Natural e Biocombustíveis, 2019). However, the supply of glycerin has exceeded its demand, mainly from the chemical, pharmaceutical and food industries, and therefore, finding new alternatives for its use (Egea et al., 2016). Considering the high glycerol content in crude glycerin, -usually between 80 and 95\%-, and its high energy value similar to corn, it has been considered as an alternative energy source in pig diets for swine production (Hanczakowska et al., 2010; Faria et al., 2015).

Addition of ractopamine in pig diets reduces the body fat content and increases the meat deposition in the carcass (Araújo et al, 2014). This makes the meat production more competitive as consumers demand high-quality, and healthy food. Individual usage of crude glycerin (Egea et al., 2016), or ractopamine (Rickard et al., 2017) in the pig diet at the finishing period leads to improvements in carcass and meat quality. However, it is necessary to assess the effects of combined usage in pig diets at the finishing period. This is the knowledge gap that we want to cover regarding the usage of glycerol, from dietary glycerin, and its metabolic potential for the triacylglycerols synthesis (Lee et al., 2001; Montell et al., 2002). We hypothesized that glycerol impacts directly on the fat deposition in the carcass and meat, while the ractopamine can modulate the lipid metabolism decreasing the lipogenesis in pigs (Ferreira et al., 2013). Thus, dietary glycerin could favor lipid deposition while ractopamine would modulate it without affecting the carcass characteristics and meat quality traits. Therefore, the objective of this study was to evaluate carcass characteristics, pork quality, and fatty acid 
profile of the loin of pigs fed with combined diets using crude glycerin and ractopamine at the finishing period.

\section{Material and methods}

\subsection{Animals, experimental design, diet and feeding}

The experiment was carried out at the Experimental Swine Center of the Animal Science Department of the Federal University of Lavras (UFLA). All experimental procedures used in this study were approved by the Ethics Committee on Animal Use of UFLA under protocol n.040/15.

Sixty-four barrows of genetic line Agroceres PIC $337 \mathrm{X}$ Camborough 25, with initial average weights of $77.2 \pm 6.0 \mathrm{~kg}$, were used. The animals were distributed in a randomized complete block design, in factorial scheme $4 \times 2$, corresponding to four concentrations of crude glycerin inclusion $(0,100,150$, or $200 \mathrm{~g} / \mathrm{kg})$ in diets without or with ractopamine $(10 \mathrm{mg} / \mathrm{kg})$. Therefore, eight treatments were evaluated, each with eight replicates of one pig (experimental unit). The criterion used for the formation of the blocks was the initial weight of the animals. The animals were individually housed in pens with concrete floors $(2.3 \times 1.5 \mathrm{~m})$, with a semi-automatic feeder and nipple drinker. The minimum temperature of the barn during the experimental period was $19.5^{\circ} \mathrm{C}$, the maximum was $29.1^{\circ} \mathrm{C}$, and the average temperature was $24.3^{\circ} \mathrm{C}$.

The crude glycerin evaluated in this study was derived from the production of biodiesel made using soybean oil and animal fat (60\% and $40 \%$, respectively) as raw materials. Its chemical composition was determined in the laboratory (Table 1), and the composition was considered in the formulation of the experimental diets (Table 2).

Experimental diets were formulated with corn and soybean meal and supplemented with minerals, vitamins, and amino acids to the nutritional requirements recommended by Rostagno et al. (2011) for barrows of high genetic potential and weighing from 70 to $100 \mathrm{~kg}$. All diets were isonutritive and isocaloric. Crude glycerin was included as substitution for corn, considering its metabolizable energy value of $3,475 \mathrm{kcal} / \mathrm{kg}$ (Melo et al., 2014). The ractopamine was added to the mix in substitution to kaolin. The Concentration used was $0.5 \mathrm{~g} / \mathrm{kg}$ in the form of ractopamine hydrochloride (Ractosuin, Ouro-Fino Saúde Animal, São Paulo, Brazil). The experimental period lasted 28 days and the pigs received water and diet ad libitum.

\subsection{Carcass characteristics}

At the end of the experimental period, the pigs were fasted for eight hours. Subsequently, they were sent to a slaughterhouse where they were desensitized by electronarcosis and slaughtered according to current Brazilian legislation.

After bleeding and evisceration, the carcasses were weighed to determine the hot carcass weight. After cooling for $24 \mathrm{~h}$, the following variables were evaluated: cold carcass weight, carcass length, fat area, loin eye area, backfat thickness and loin depth, at the position of the last rib, according to Bridi \& Silva (2009). The hot and cold carcass yields were estimated based in the equation: \% Carcass yield $=($ Carcass weight $x 100) /$ Live weight .
Table 1. Chemical composition of crude glycerin ${ }^{1}$ (as-fed basis).

\begin{tabular}{lc}
\hline \multicolumn{1}{c}{ Characteristics } & Analyzed composition ${ }^{2}$ \\
\hline Moisture and volatiles $(\mathrm{g} / \mathrm{kg})$ & 132.9 \\
Glycerol $(\mathrm{g} / \mathrm{kg})$ & 803.0 \\
Crude protein $(\mathrm{g} / \mathrm{kg})$ & 0.35 \\
Sodium $(\mathrm{g} / \mathrm{kg})$ & 19.7 \\
Potassium $(\mathrm{g} / \mathrm{kg})$ & 0.5 \\
Ash $(\mathrm{g} / \mathrm{kg})$ & 52.4 \\
Methanol $(\mathrm{g} / \mathrm{kg})$ & 12.0 \\
pH & 7.0 \\
\hline${ }^{1}$ Crude glycerin $(\mathrm{CG})$ obtained from soybean oil and animal fat ${ }^{2}$ Chemical analyses were \\
performed by the CBO Analysis Laboratory (Campinas, São Paulo, Brazil).
\end{tabular}

Table 2. Ingredients and chemical composition of the experimental diets (as-fed basis).

\begin{tabular}{|c|c|c|c|c|}
\hline & \multicolumn{4}{|c|}{ Crude glycerin concentration in the diet } \\
\hline Item & $0 \mathrm{~g} / \mathrm{kg}$ & $100 \mathrm{~g} / \mathrm{kg}$ & $150 \mathrm{~g} / \mathrm{kg}$ & $200 \mathrm{~g} / \mathrm{kg}$ \\
\hline \multicolumn{5}{|c|}{ Ingredients $(\mathrm{g} / \mathrm{kg})$} \\
\hline Corn & 763.0 & 654.5 & 599.0 & 541.5 \\
\hline Crude glycerin & 0.0 & 100.0 & 150.0 & 200.0 \\
\hline Soybean meal, $45 \%$ & 191.5 & 210.6 & 220.4 & 230.7 \\
\hline Soybean oil & 14.0 & 9.1 & 7.0 & 5.6 \\
\hline Dicalcium phosphate & 8.5 & 8.5 & 8.6 & 8.7 \\
\hline Limestone & 5.8 & 5.7 & 5.7 & 5.6 \\
\hline Sodium chloride & 9.8 & 4.9 & 2.5 & 0.0 \\
\hline Vitamin-mineral supplement ${ }^{1}$ & 2.0 & 2.0 & 2.0 & 2.0 \\
\hline L-Lysine $\mathrm{HCl}, 99 \%$ & 2.5 & 2.2 & 2.0 & 1.8 \\
\hline DL-Methionine, 99\% & 0.3 & 0.4 & 0.5 & 0.5 \\
\hline L-Threonine & 0.5 & 0.5 & 0.5 & 0.5 \\
\hline Kaolin $^{2}$ & 2.1 & 1.6 & 1.8 & 3.0 \\
\hline \multicolumn{5}{|c|}{ Calculated nutritional composition $(\mathrm{g} / \mathrm{kg})$} \\
\hline Glycerin & 0.0 & 100.0 & 150.0 & 200.0 \\
\hline Glycerol $^{3}$ & 0.0 & 80.3 & 120.5 & 160.6 \\
\hline Crude protein $(\mathrm{N} \times 6,25)$ & 150 & 150 & 150 & 150 \\
\hline Metabolizable energy (MJ/kg) & 13.8 & 13.8 & 13.8 & 13.8 \\
\hline Calcium & 5.0 & 5.0 & 5.0 & 5.0 \\
\hline Available phosphorus & 2.4 & 2.4 & 2.4 & 2.4 \\
\hline Sodium & 4.1 & 4.1 & 4.1 & 4.1 \\
\hline Methionine + cystine & 4.8 & 4.8 & 4.8 & 4.8 \\
\hline Digestible lysine & 8.3 & 8.3 & 8.3 & 8.3 \\
\hline Digestible threonine & 5.6 & 5.6 & 5.6 & 5.6 \\
\hline \multicolumn{5}{|c|}{$\begin{array}{l}\text { 'Qualitec S. Acabamento' (Trouw Nutrition, São Paulo, Brasil). Composition (per kg): } \\
\text { vitamin A, } 2500000 \mathrm{IU} \text {; vitamin B1, } 250 \mathrm{mg} \text {; vitamin B12, 5,000 mcg; vitamin B2, } 1200 \\
\text { mg; vitamin B6, } 400 \mathrm{mg} \text {; vitamin D3, } 300,000 \mathrm{IU} \text {; vitamin E, } 4,000 \mathrm{IU} \text {; vitamin K3, } 500 \\
\mathrm{mg} \text { biotin, } 5 \mathrm{mg} \text {; choline, } 32.5 \mathrm{~g} \text {; niacin, 7,500 mg; pantothenic acid, } 3600 \mathrm{mg} \text {; cobalt, } \\
100 \mathrm{mg} \text {; copper, } 22.5 \mathrm{~g} \text {; iron, } 40 \mathrm{~g} \text {; iodine, } 100 \mathrm{mg} \text {; manganese, } 21 \mathrm{~g} \text {; selenium, } 75 \mathrm{mg} \text {; } \\
\text { zinc, } 40 \mathrm{~g} \text {; lysine, } 113.1 \mathrm{~g} \text {; Bacillus subtillis } 75 \times 10^{9} \mathrm{UFC} \text {; }{ }^{2} \text { Kaolin is an inert ingredient. } \\
\text { For the experimental diets, the ractopamine was added in substitution to kaolin in the } \\
\text { inclusion level of } 0.5 \mathrm{~g} / \mathrm{kg} \text {. Ractopamine hydrochloride } 2 \% \text { (Ouro-fino Saúde Animal, } \\
\text { Cravinhos, Brasil) was used; }{ }^{3} \text { Estimated according to the glycerin concentration in the } \\
\text { diet and the glycerol content determined in glycerin ( } 803 \mathrm{~g} / \mathrm{kg} \text {; Table } 1 \text { ). }\end{array}$} \\
\hline
\end{tabular}

\subsection{Physical and chemical traits}

$\mathrm{PH}$ and temperature were measured in the Longissimus thoracis portion, i.e. the last rib, using a $\mathrm{pH}$ meter (Hanna Instruments ${ }^{\circ} \mathrm{HI} 99163$, Romania). The initial $\mathrm{pH}$ and temperature 
were measured $45 \mathrm{~min}$ after slaughter, while the final $\mathrm{pH}$ and temperature were measured $24 \mathrm{~h}$ after slaughter.

Color evaluation was measured at $24 \mathrm{~h}$ post mortem, using a colorimeter (Konica Minolta CM-700, Singapore), with a CIELAB system, and D65 illuminant, at an observer angle of $10^{\circ}, \mathrm{MAV}(11 \mathrm{~mm})$ and Specular Component Excluded (SCE) to obtain the indexes lightness $\left(\mathrm{L}^{*}\right)$, redness $\left(\mathrm{a}^{*}\right)$ and yellowness $\left(\mathrm{b}^{\star}\right)$. Saturation $\left(\mathrm{C}^{*}\right)$ and hue angle $\left(\mathrm{h}^{*}\right)$ were calculated using equations proposed by Ramos \& Gomide (2012) in which $\mathrm{C}^{\star}=\left(\mathrm{a}^{\star} 2+\mathrm{b}^{\star} 2\right) 1 / 2$ and $\mathrm{h}^{*}=\tan -1\left(\mathrm{~b}^{*} / \mathrm{a}^{*}\right)$.

Cooking loss was evaluated according to the technique described by Bridi \& Silva (2009). Meat samples were wrapped in aluminum foil and broiled on a preheated electric grill of $170^{\circ} \mathrm{C}$ (Mega Grill; Britânia, Curitiba, PR, Brazil), to an internal temperature of $72{ }^{\circ} \mathrm{C}$. Drip loss determination was performed using the suspension technique described in Ramos \& Gomide (2012) with a 48 -hour duration at $5^{\circ} \mathrm{C}$. Results were reported as a percentage of the initial weight. Shear force determination was performed in samples with a cross-section of $1.0 \mathrm{~cm} \times 1.0 \mathrm{~cm}$ using a Warner Bratzler probe coupled to a texturometer (Extralab, model TA.XT plus, Jarinu, SP, Brazil), gauged to cut at the speed of $2 \mathrm{~mm} / \mathrm{s}$, and the SF results were expressed by Newtons $(\mathrm{N})$.

Loin samples were also used to determine the centesimal composition (moisture, crude protein, ether extract and ash) and were evaluated, respectively, according to the methods 950.46, 991.36, 726.08, and 923.03 respectively of the Association of Official Analytical Chemists (Latimer, 2016).

\subsection{Lipid profile}

The fatty acids profile in the loin was performed by the extraction method described by Folch et al. (1957) and esterification as described by Hartman \& Lago (1973). The extracts were submitted to gas chromatography on a Shimatzu CG 2010 chromatograph (Agilent Technologies Inc., Palo Alto, CA, USA), equipped with an AOC 20 I split injector in a ratio of 1:100 split, and capillary column Supelco SPTM-2560, $100 \mathrm{~m} \mathrm{X} 0.25$ mm X $0.20 \mu \mathrm{m}$ (Supelco Inc., Bellefonte, PA, USA). The chromatographic conditions were as follows: initial column temperature of $140^{\circ} \mathrm{C} / 5 \mathrm{~min}$, elevation from $4^{\circ} \mathrm{C} / \mathrm{min}$ to $240{ }^{\circ} \mathrm{C}$ and maintenance for $30 \mathrm{~min}$, for a total of $60 \mathrm{~min}$. The temperatures of the injector and the sampler were maintained at $260{ }^{\circ} \mathrm{C}$. The carrier gas used was helium. The linear velocity was $28 \mathrm{~cm} / \mathrm{sec}$, and the column flow was $2 \mathrm{ml} / \mathrm{min}$.

Fatty acids were identified by comparison with the retention times presented by the chromatography standard Supelco ${ }^{\text {tw }} 37$ standard FAME Mix 47885-U (Supelco Inc., Bellefonte, PA, USA) and expressed as a percentage of total identified fatty acids. Later, fatty acids were grouped as total saturated fatty acids (SFA), total monounsaturated fatty acids (MUFA), total polyunsaturated fatty acids (PUFA), total omega 6 and omega 3 fatty acids, and their ratios.

The rates of atherogenicity and thrombogenicity, considered health indicators related to the risk of cardiovascular disease, were calculated according to Ulbricht \& Southgate (1991) using the following equations: the atherogenicity index $=[4(\mathrm{C} 14: 0)+$ C16:0] / ( MUFA + $\Sigma$ PUFA $)$, and the thrombogenicity index $=$ $(\mathrm{C} 14: 0+\mathrm{C} 16: 0+\mathrm{C} 18: 0) /[(0.5 \mathrm{x} \Sigma \mathrm{MUFA})+(0.5 \mathrm{x} \Sigma \omega-6)+(3 \mathrm{x}$ $\Sigma \omega-3)+(\Sigma \omega-3 / \omega-6)]$. The activity indexes of the $\Delta 9$-desaturase, elongase, and thioesterase enzymes were estimated according to Malau-Aduli et al. (1997). The cholesterol content in the loin was determined colorimetrically according to the method of Bohac \& Rhee (1988).

\subsection{Statistical analysis}

All variables measured were tested for normality by the Shapiro-Wilk test before analysis, and any variable that failed to follow a normal distribution was transformed through the RANK procedure of SAS (SAS Inst. Inc., Cary, NC). The PROC RANK statement with the NORMAL option was used to produce a normalized transformed variable. All data were analyzed using the MIXED procedure of SAS (SAS Institute Inc., Cary, NC, USA) as a randomized complete block design (initial weight of the pigs) in a factorial scheme with inclusion of crude glycerin $(0,100,150$ or $200 \mathrm{~g} / \mathrm{kg}$ ), inclusion or not of ractopamine $(0$ or $10 \mathrm{mg} / \mathrm{kg}$ ) and interaction effect between glycerin level and ractopamine inclusion. Each pig was considered an experimental unit. Initial analyses found no significant interactions, and consequently these were deleted from the model. The effect of ractopamine inclusion was determined using an $\mathrm{F}$ test. Non-significant effects were found for the glycerin levels, and no regression analysis was performed. Results include least squares means, and the greatest standard errors (SEM). Significant differences were reported considering $\alpha=0.05$.

\section{Results}

There was no interaction $(\mathrm{p}>0.05)$ between ractopamine and crude glycerin nor an isolated effect $(\mathrm{p}>0.05)$ of the crude glycerin concentrations in the diet for all carcass characteristics evaluated (Table 3 ). The dietary ractopamine increased $(\mathrm{p}<0.05)$ the hot carcass weight, hot carcass yield, and cold carcass weight but did not affect ( $p>0.05)$ cold carcass yield, carcass length, fat area, loin depth, and backfat thickness.

No significant interaction $(\mathrm{p}>0.05)$ between dietary ractopamine and glycerin was observed. Isolated effects $(p>0.05)$ of crude glycerin concentrations on all pork quality traits $(\mathrm{pH}$, Temperature, Color, Cooking/Drip Loss, Shear Force, Centesimal composition and Cholesterol) of the loin (Table 4) were not significant either. The use of ractopamine increased $(\mathrm{p}<0.05)$ the shear force, the indexes $L^{*}$ (lightness) and $\mathrm{h}^{*}$ (hue angle), and decreased $(\mathrm{p}<0.05)$ the value of $\mathrm{a}^{\star}($ red content $)$ in the loin.

No significant interaction $(\mathrm{p}>0.05)$ between ractopamine and glycerin was computed. There was no effect of crude glycerin $(p>0.05)$ on the loin fatty acid profile and other traits of the lipid composition (Table 5). The dietary ractopamine increased $(\mathrm{p}<0.05)$ the $\mathrm{C} 16: 1$ concentration and decreased $(\mathrm{p}<0.05)$ the $\mathrm{C} 18: 0$ concentration and the activity estimate of the elongase ${ }^{\mathrm{C} 16-\mathrm{C} 18}$ in the loin. There were no differences ( $p>0.05$ ) among the dietary treatments for the atherogenicity and thrombogenicity rates. 
Table 3. Carcass characteristics of finishing pigs fed diets formulated with different crude glycerin concentrations, without or with addition of ractopamine.

\begin{tabular}{|c|c|c|c|c|c|c|c|c|c|}
\hline \multirow{2}{*}{ Characteristics } & \multicolumn{2}{|c|}{ Ractopamine (mg/kg) } & \multicolumn{4}{|c|}{ Crude glycerin (g/kg) } & \multirow{2}{*}{ SEM } & \multicolumn{2}{|c|}{ p-value ${ }^{1}$} \\
\hline & 0 & 10 & 0 & 100 & 150 & 200 & & RAC & CG \\
\hline Hot carcass weight (kg) & $81.2^{\mathrm{b}}$ & $83.2^{\mathrm{a}}$ & 82.0 & 82.8 & 82.2 & 81.8 & 2.35 & 0.021 & 0.831 \\
\hline Hot carcass yield (\%) & $78.7^{\mathrm{b}}$ & $79.6^{\mathrm{a}}$ & 78.9 & 78.9 & 79.3 & 79.5 & 0.51 & 0.038 & 0.720 \\
\hline Cold carcass weight $(\mathrm{kg})$ & $79.0^{\mathrm{b}}$ & $80.9^{\mathrm{a}}$ & 79.9 & 80.4 & 79.9 & 79.7 & 2.35 & 0.020 & 0.918 \\
\hline Cold carcass yield (\%) & 76.6 & 77.4 & 76.8 & 76.6 & 77.0 & 77.5 & 0.55 & 0.061 & 0.774 \\
\hline Carcass length (cm) & 95.3 & 94.4 & 95.8 & 94.1 & 94.4 & 95.2 & 0.76 & 0.222 & 0.375 \\
\hline Loin eye area $\left(\mathrm{cm}^{2}\right)$ & 51.8 & 52.5 & 52.7 & 52.3 & 51.8 & 51.9 & 1.15 & 0.425 & 0.869 \\
\hline Backfat thickness (mm) & 13.9 & 13.1 & 13.6 & 13.6 & 13.2 & 13.5 & 0.70 & 0.228 & 0.987 \\
\hline Loin depth (mm) & 73.6 & 73.5 & 74.7 & 75.1 & 72.2 & 72.2 & 1.23 & 0.935 & 0.198 \\
\hline Fat area $\left(\mathrm{cm}^{2}\right)$ & 17.5 & 17.1 & 17.1 & 18.6 & 16.5 & 17.2 & 0.95 & 0.674 & 0.462 \\
\hline
\end{tabular}

SEM, mean standard error; RAC, ractopamine; CG, crude glycerin. ${ }^{\text {a-b }}$ Means followed by different lowercase letters in the same row differ from each other at a $5 \%$ significance level;

${ }^{1}$ For all evaluated characteristics, there was no interaction $(\mathrm{p}>0.05)$ between crude glycerin and ractopamine in the diet.

Table 4. Quality traits, color, and centesimal composition of the loin (Longissimus lumborum) of finishing pigs fed diets formulated with different crude glycerin concentrations, without or with addition of ractopamine.

\begin{tabular}{|c|c|c|c|c|c|c|c|c|c|}
\hline \multirow{2}{*}{ Traits } & \multicolumn{2}{|c|}{ Ractopamine (mg/kg) } & \multicolumn{4}{|c|}{ Crude glycerin $(\mathrm{g} / \mathrm{kg})$} & \multirow{2}{*}{ SEM } & \multicolumn{2}{|c|}{ p-value ${ }^{1}$} \\
\hline & 0 & 10 & 0 & 100 & 150 & 200 & & RAC & CG \\
\hline $\mathrm{pH} 45 \mathrm{~min}$ & 6.2 & 6.2 & 6.1 & 6.2 & 6.2 & 6.2 & 0.06 & 0.944 & 0.462 \\
\hline $\mathrm{pH} 24 \mathrm{~h}$ & 5.7 & 5.6 & 5.8 & 5.5 & 5.7 & 5.7 & 0.12 & 0.471 & 0.054 \\
\hline Temperature $45 \min \left({ }^{\circ} \mathrm{C}\right)$ & 33.6 & 32.8 & 33.8 & 33.6 & 32.9 & 32.4 & 0.82 & 0.113 & 0.353 \\
\hline Temperature $24 \mathrm{~h}\left({ }^{\circ} \mathrm{C}\right)$ & 5.8 & 6.2 & 5.9 & 6.1 & 6.0 & 5.9 & 0.56 & 0.338 & 0.995 \\
\hline Cooking loss (\%) & 33.4 & 33.1 & 34.4 & 32.5 & 32.9 & 33.2 & 0.96 & 0.745 & 0.517 \\
\hline Drip loss 24 h (\%) & 4.6 & 4.8 & 4.5 & 4.7 & 5.0 & 4.5 & 0.40 & 0.849 & 0.840 \\
\hline Drip loss 48 h (\%) & 6.0 & 6.1 & 6.1 & 5.8 & 6.4 & 5.8 & 0.40 & 0.688 & 0.765 \\
\hline Shear force $(\mathrm{N})$ & $47.0^{\mathrm{b}}$ & $58.8^{\mathrm{a}}$ & 55.9 & 51.9 & 48.0 & 56.8 & 2.84 & $<0.0001$ & 0.120 \\
\hline Lightness - L* & $57.2^{\mathrm{b}}$ & $58.0^{\mathrm{a}}$ & 57.2 & 57.7 & 57.6 & 57.9 & 0.41 & 0.043 & 0.683 \\
\hline Redness - $\mathrm{a}^{*}$ & $0.7^{\mathrm{a}}$ & $0.4^{\mathrm{b}}$ & 0.7 & 0.7 & 0.5 & 0.3 & 0.16 & 0.043 & 0.142 \\
\hline Yellowness - $\mathrm{b}^{*}$ & 11.5 & 11.2 & 11.5 & 11.4 & 11.3 & 11.0 & 0.18 & 0.125 & 0.234 \\
\hline Saturation index $-C^{*}$ & 11.5 & 11.2 & 11.6 & 11.4 & 11.4 & 11.1 & 0.13 & 0.106 & 0.221 \\
\hline Hue angle - $\mathrm{h}^{\star}$ & $86.3^{\mathrm{b}}$ & $88.2^{\mathrm{a}}$ & 86.0 & 86.5 & 87.5 & 88.9 & 0.58 & 0.026 & 0.085 \\
\hline Moisture (\%) & 73.2 & 73.1 & 73.1 & 73.2 & 73.2 & 73.0 & 0.46 & 0.787 & 0.992 \\
\hline Ether extract (\%) & 1.6 & 2.0 & 1.8 & 1.6 & 2.0 & 1.8 & 0.20 & 0.109 & 0.339 \\
\hline Crude protein (\%) & 24.0 & 23.5 & 23.4 & 23.6 & 23.9 & 24.2 & 0.40 & 0.218 & 0.486 \\
\hline Ash (\%) & 1.3 & 1.3 & 1.3 & 1.3 & 1.3 & 1.3 & 0.03 & 0.385 & 0.726 \\
\hline Cholesterol (mg/100 g) & 93.1 & 91.1 & 90.3 & 90.6 & 96.1 & 91.5 & 5.59 & 0.914 & 0.851 \\
\hline
\end{tabular}

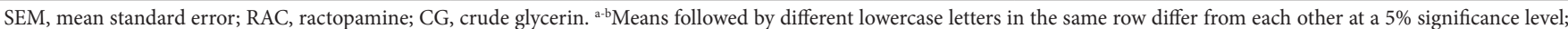

${ }^{1}$ For all evaluated traits, there was no interaction $(\mathrm{p}>0.05)$ between crude glycerin and ractopamine in the diet.

\section{Discussion}

Our results regarding the carcass characteristics are in accordance to those reported by other authors (Mendoza et al., 2010; Egea et al., 2016) for backfat thickness, since the energy value of glycerin is similar to that of corn (Melo et al., 2014).

The increases in hot and cold carcass weight corroborated the results found by Silva et al. (2013), and the increase in the hot carcass yield in this study agrees with those observed by Rickard et al. (2017) in pigs fed diets containing ractopamine. Ractopamine can increase the proportion of nutrients deposited in the carcass relative to that deposited in organs or non-carcass components (Mills, 2002), as no significant differences were observed in else carcass characteristics (loin eye area, backfat, thickness, loin depth, and fat area).

The addition of ractopamine to the diet did not alter the $\mathrm{pH}$ or temperature of the pork, as found in another study (Amin et al., 2015). The dietary crude glycerin also did not alter the $\mathrm{pH}$ of the pork, as shown in the research of Egea et al. (2016) with the use of glycerin at up to $10 \mathrm{mg} / \mathrm{kg}$ of diet. Moreover, the results obtained for pork loin quality corroborate the reports of Melo et al. (2014), who concluded that the dietary glycerin did not promote changes in the traits of lightness, redness, yellowness, color saturation index, hue angle, $\mathrm{pH}$ at $45 \mathrm{~min}$, $\mathrm{pH}$ at $24 \mathrm{~h}$, cooking loss, and shear force. 
Table 5. Fatty acids profile in the loin (Longissimus lumborum) of finishing pigs fed diets formulated with different crude glycerin concentrations, without or with addition of ractopamine.

\begin{tabular}{|c|c|c|c|c|c|c|c|c|c|}
\hline \multirow{2}{*}{ Fatty acids (\%) } & \multicolumn{2}{|c|}{ Ractopamine (mg/kg) } & \multicolumn{4}{|c|}{ Crude glycerin $(\mathrm{g} / \mathrm{kg})$} & \multirow{2}{*}{ SEM } & \multicolumn{2}{|c|}{ p-value ${ }^{1}$} \\
\hline & 0 & 10 & 0 & 100 & 150 & 200 & & RAC & CG \\
\hline C10:0 & 0.09 & 0.10 & 0.10 & 0.09 & 0.09 & 0.10 & 0.003 & 0.316 & 0.978 \\
\hline $\mathrm{C} 12: 0$ & 0.09 & 0.10 & 0.10 & 0.10 & 0.10 & 0.10 & 0.002 & 0.536 & 0.458 \\
\hline C14:0 & 1.16 & 1.19 & 1.21 & 1.17 & 1.17 & 1.17 & 0.012 & 0.261 & 0.554 \\
\hline C14:1 & 0.02 & 0.03 & 0.03 & 0.02 & 0.02 & 0.02 & 0.001 & 0.323 & 0.059 \\
\hline C15:0 & 0.09 & 0.10 & 0.10 & 0.10 & 0.09 & 0.10 & 0.003 & 0.609 & 0.369 \\
\hline $\mathrm{C} 16: 0$ & 24.92 & 25.22 & 25.37 & 24.98 & 25.13 & 24.83 & 0.120 & 0.242 & 0.409 \\
\hline C16:1 & $3.21^{\mathrm{b}}$ & $3.46^{\mathrm{a}}$ & 3.35 & 3.27 & 3.43 & 3.28 & 0.053 & 0.023 & 0.757 \\
\hline $\mathrm{C} 17: 0$ & 0.43 & 0.42 & 0.38 & 0.44 & 0.45 & 0.44 & 0.012 & 0.622 & 0.137 \\
\hline $\mathrm{C} 17: 1$ & 0.83 & 0.86 & 0.79 & 0.86 & 0.85 & 0.90 & 0.025 & 0.585 & 0.530 \\
\hline C18:0 & $11.49^{\mathrm{a}}$ & $11.07^{\mathrm{b}}$ & 11.22 & 11.35 & 11.30 & 11.25 & 0.083 & 0.021 & 0.916 \\
\hline $\mathrm{C} 18: 1 \omega 9 \mathrm{t}$ & 0.15 & 0.15 & 0.13 & 0.15 & 0.16 & 0.15 & 0.004 & 0.667 & 0.068 \\
\hline $\mathrm{C} 18: 1 \omega 9 \mathrm{c}$ & 44.07 & 43.73 & 43.20 & 43.30 & 44.67 & 44.43 & 0.312 & 0.453 & 0.337 \\
\hline $\mathrm{C} 18: 2 \omega 6 \mathrm{c}$ & 9.36 & 9.41 & 9.92 & 9.87 & 8.80 & 8.95 & 0.246 & 0.828 & 0.286 \\
\hline C20:0 & 0.16 & 0.17 & 0.16 & 0.16 & 0.18 & 0.15 & 0.003 & 0.240 & 0.085 \\
\hline $\mathrm{C} 18: 3 \omega 6$ & 0.08 & 0.07 & 0.07 & 0.08 & 0.08 & 0.08 & 0.003 & 0.719 & 0.343 \\
\hline C20:1 & 0.76 & 0.78 & 0.75 & 0.73 & 0.79 & 0.80 & 0.014 & 0.690 & 0.200 \\
\hline $\mathrm{C} 18: 3 \omega 3$ & 0.01 & 0.01 & 0.01 & 0.01 & 0.02 & 0.01 & 0.007 & 0.977 & 0.243 \\
\hline C21:0 & 0.04 & 0.05 & 0.04 & 0.04 & 0.04 & 0.06 & 0.004 & 0.334 & 0.355 \\
\hline C20:2 & 0.27 & 0.26 & 0.28 & 0.26 & 0.25 & 0.26 & 0.005 & 0.812 & 0.258 \\
\hline $\mathrm{C} 20: 3 \omega 6$ & 0.29 & 0.28 & 0.28 & 0.31 & 0.26 & 0.30 & 0.010 & 0.763 & 0.455 \\
\hline $\mathrm{C} 20: 3 \omega 3$ & 0.04 & 0.04 & 0.04 & 0.04 & 0.04 & 0.03 & 0.003 & 0.710 & 0.645 \\
\hline C20:4w6 & 2.15 & 2.06 & 2.08 & 2.25 & 1.96 & 2.12 & 0.077 & 0.691 & 0.733 \\
\hline C20:5 23 & 0.05 & 0.05 & 0.05 & 0.05 & 0.05 & 0.04 & 0.002 & 0.896 & 0.692 \\
\hline $\mathrm{C} 22: 6 \omega 3$ & 0.05 & 0.05 & 0.05 & 0.06 & 0.05 & 0.04 & 0.002 & 0.771 & 0.078 \\
\hline $\mathrm{SFA}^{2}$ & 38.32 & 38.15 & 38.48 & 38.22 & 38.38 & 37.86 & 0.161 & 0.628 & 0.556 \\
\hline MUFA $^{3}$ & 48.80 & 48.72 & 48.01 & 48.12 & 49.48 & 49.42 & 0.321 & 0.759 & 0.292 \\
\hline PUFA $^{4}$ & 12.50 & 12.39 & 12.98 & 13.02 & 11.73 & 12.07 & 0.326 & 0.973 & 0.505 \\
\hline$\sum \omega 3^{5}$ & 0.41 & 0.40 & 0.43 & 0.41 & 0.40 & 0.38 & 0.009 & 0.812 & 0.254 \\
\hline$\sum \omega 6^{6}$ & 11.88 & 11.76 & 12.34 & 12.37 & 11.10 & 11.45 & 0.315 & 0.956 & 0.490 \\
\hline$\sum \omega 6 / \sum \omega 3^{7}$ & 28.55 & 28.96 & 29.11 & 29.37 & 27.05 & 29.49 & 0.484 & 0.670 & 0.394 \\
\hline PUFA/SFA ${ }^{8}$ & 0.32 & 0.33 & 0.34 & 0.33 & 0.30 & 0.32 & 0.009 & 0.604 & 0.516 \\
\hline${ }^{9} \Delta 9$-desaturase ${ }^{\mathrm{C} 16}$ & 0.11 & 0.12 & 0.12 & 0.12 & 0.12 & 0.12 & 0.002 & 0.098 & 0.911 \\
\hline${ }^{10} \Delta 9$-desaturase ${ }^{\mathrm{C} 18}$ & 0.79 & 0.80 & 0.80 & 0.79 & 0.80 & 0.80 & 0.002 & 0.340 & 0.707 \\
\hline${ }^{11}$ Elongase ${ }^{\mathrm{C} 16-\mathrm{C} 18}$ & $0.66^{\mathrm{a}}$ & $0.65^{\mathrm{b}}$ & 0.65 & 0.66 & 0.66 & 0.66 & 0.001 & 0.037 & 0.060 \\
\hline${ }^{12}$ Thioesterase ${ }^{\mathrm{C} 16-14}$ & 0.96 & 0.98 & 0.95 & 0.96 & 0.96 & 0.90 & 0.018 & 0.980 & 0.828 \\
\hline Atherogenicity & 0.58 & 0.57 & 0.55 & 0.58 & 0.60 & 0.59 & 0.012 & 0.796 & 0.715 \\
\hline Thrombogenicity & 8.64 & 8.59 & 8.99 & 8.93 & 8.20 & 8.34 & 0.189 & 0.970 & 0.399 \\
\hline
\end{tabular}

SEM, mean standard error; RAC, ractopamine; CG, crude glycerin. ${ }^{\mathrm{a}-\mathrm{b}}$ Means followed by different lowercase letters in the same row differ from each other at a $5 \%$ significance level; ${ }^{1}$ For all evaluated traits, there was no interaction $(\mathrm{p}>0.05)$ between crude glycerin concentration and ractopamine in the diet; ${ }^{2}$ Sum of the saturated fatty acids $($ SFA) $(\mathrm{C} 12: 0+\mathrm{C} 14: 0$ $+\mathrm{C} 15: 0+\mathrm{C} 16: 0+\mathrm{C} 17: 0+\mathrm{C} 18: 0+\mathrm{C} 20: 0) ;{ }^{3}$ Sum of the monounsaturated fatty acids (MUFA) $\left(\mathrm{C} 14: 1\right.$ cis-9+C16:1 cis-9+ C17:1 cis-9+C18:1 cis-9+C20:1 cis-9 + C22:1 cis-9); ${ }^{4}$ Sum

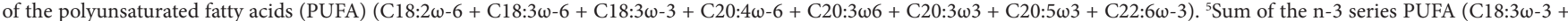

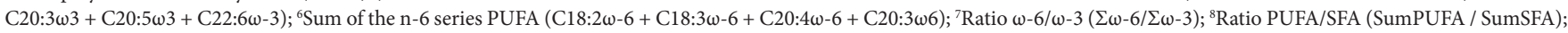
${ }^{9}$ Desaturase activity index C16 = $100\left[\left(\mathrm{C} 16: 1\right.\right.$ cis-9)/(C16:1 cis-9 + C16:0)]; ${ }^{10}$ Desaturase activity index C18 = 100 [(C18:1 cis-9)/(C18:1 cis-9 + C18:0)]; ${ }^{11}$ Elongase activity index C16 to $\mathrm{C} 18=100\left[\left(\mathrm{C} 18: 0+\mathrm{C} 18: 1\right.\right.$ cis-9) $/(\mathrm{C} 16: 0+\mathrm{C} 16: 1$ cis-9 $+\mathrm{C} 18: 0+\mathrm{C} 18: 1$ cis-9) $]$; ${ }^{12}$ Thioesterase activity index C16 to C14 = 100 $[(\mathrm{C} 16: 0) /(\mathrm{C} 16: 0+\mathrm{C} 14: 0)]$.

The levels of ash, moisture, protein, and ethereal extract in the loin determined in this work were not influenced by crude glycerin concentrations, as reported by Melo et al. (2014) and
Egea et al. (2016). In its turn, the influence of dietary ractopamine on the increase in the shear force of the loin may be related to a reduction in the activity of calpain proteases (Xiong et al., 2006) 
due to the greater gene expression related to calpastatin isoforms (Parr et al., 2004), and may be associated with increased muscle fiber diameter (Li et al., 2015).

The mean values observed in the present study for yellowness (11.34) and saturation index or chroma (11.37) are in accordance with the values reported in the literature (Silva et al., 2013). Pigs fed ractopamine $(10 \mathrm{mg} / \mathrm{kg})$ during the finishing phase may exhibit lighter meat due to a reduction in red content and a concomitant increase in lightness. The decrease in redness suggests that in the presence of this additive, there is a reduction in the oxymyoglobin concentration resulting in a lighter meat because of the decreased amount of iron present in the tissue (Lindahl et al., 2001). As verified in the present study, Agostini et al. (2011) also found that pork has a lower red intensity when ractopamine is added to the pig diet.

The constancy of the fatty acid profiles in the loin of pigs fed with different glycerin concentrations is contrary to the results reported by Faria et al. (2015). They found changes in fatty acid deposition with higher amounts of glycerin in pig diet. These results are important as the meat flavor is influenced by the intramuscular composition of fatty acids (Muriel et al., 2004). Moreover, in this study, no changes were observed in concentrations of MUFA, PUFA, or linoleic acid in the loin of pigs fed diet containing ractopamine. However, there was a decrease in stearic acid and increase in palmitoleic acid with the addition of ractopamine in the pig diets. In contrast to our study, Apple et al. (2008) observed an increase in PUFA and linoleic acid concentrations and a decrease in the concentrations of SFA and MUFA in the pork of pigs fed ractopamine. Pork fat composition in pigs fed with ractopamine and glycerin could be variable due to the actual input of these ingredients, i.e. the contents of glycerol, and ractopamine in the diets.

The decrease in the estimated activity of the enzyme elongase $\mathrm{e}^{\mathrm{C} 16-\mathrm{Cl} 18}$ in the loin caused by dietary ractopamine may be related to a decrease in the synthesis of triacylglycerols in the pork (Nakamura \& Nara, 2004). Already the atherogenicity and thrombogenicity indexes are related to the amounts of fatty acids saturated, polyunsaturated, $\omega-3$, and $\omega-6$, being health indicators associated with the risk of cardiovascular disease (Ulbricht \& Southgate, 1991). Thus, the lower the atherogenicity and thrombogenicity indexes of a given food are, the better the health benefits. The mean rates of atherogenicity and thrombogenicity found in this study were higher than those found in the study by Faria et al. (2015) for barrows. These discrepancies may be the result of different dietary lipid profiles among studies, as the addition of ractopamine and glycerin in the diet did not increase the atherogenicity and thrombogenicity indexes.

Our results showed that these ingredients, and their association, have potential application in swine meat production if their usage could reduce costs and caused no detrimental effects on pork quality.

\section{Conclusion}

The inclusion of up to $200 \mathrm{~g} / \mathrm{kg}$ crude glycerin in the diet of finishing pigs may be used as a partial substitute for dietary corn, combined or not with $10 \mathrm{mg} / \mathrm{kg}$ ractopamine, without impair the evaluated carcass characteristics and the quality of the loin.

\section{Acknowledgements}

We would like to offer special thanks to Dr. Raimundo V. Souza (in memorian), who although no longer with us, continues to inspire by his example, dedication and for his contribution to the research (conception and design of study, methodology, supervision and funding acquisition). To Petrobras Biocombustível S.A. (Montes Claros, Minas Gerais, Brazil) for the supply of crude glycerin and the Ouro-Fino Saúde Animal for the supply of ractopamine. This experiment was financial supported by the Conselho Nacional de Desenvolvimento Científico e Tecnológico (CNPq), the Coordenação de Aperfeiçoamento de Pessoal de Nível Superior (CAPES), and the Fundação de Amparo à Pesquisa do Estado de Minas Gerais (FAPEMIG; process no. CVZ - APQ-02766-14).

\section{References}

Agência Nacional do Petróleo, Gás Natural e Biocombustíveis - ANP. (2019). Retrieved from http://www.anp.gov.br/dados-estatisticos

Agostini, P. S., Silva, C. A., Agostini, P. S., Silva, C. A., Bridi, A. M., Abrami, R. A. M., Pacheco, G. D., Lozano, A. P., Ywazaki, M. S., Dalto, D. B., Gavioli, D. F., Oliveira, E. R., Bonafé, E. G., Souza, N. E., \& Visentainer, J. V.. (2011). Effects of ractopamine on performance and physiology of pigs. Archivos de Zootecnia, 60(231), 659-670. http://dx.doi.org/10.4321/S0004-05922011000300054.

Amin, M., Kiefer, C., Lara, J. A. F., Marçal, D. A., Abreu, R. C., Rodrigues, G. P., Alencar, S. A. S., \& Freitas, H. B. (2015). Efeito do período de suplementação de ractopamina na dieta em relação à qualidade da carne suína. Revista Acadêmica de Ciência Animal, 13, 167-175. http://dx.doi.org/10.7213/academica.13.FC.AO18.

Apple, J. K., Maxwell, C. V., Kutz, B. R., Rakes, L. K., Sawyer, J. T., Johnson, Z. B., Armstrong, T. A., Carr, S. N., \& Matzat, P. D. (2008). Interactive effect of ractopamine and dietary fat source on pork quality characteristics of fresh pork chops during simulated retail display. Journal of Animal Science, 86(10), 2711-2722. http://dx.doi. org/10.2527/jas.2007-0327. PMid:18502886.

Araújo, T. S., Porto, L. C. J., Mario, E. G., Pereira, L. J., Ferreira, M. S. S., Zangerônimo, M. G., Napimoga, M. H., Botion, L. M., \& Sousa, R. V. (2014). Ractopamine effect on lipid metabolism and GLUT4 amount of finishing pigs. Turkish Journal of Veterinary and Animal Sciences, 38(1), 54-62. http://dx.doi.org/10.3906/vet-1304-65.

Bohac, C. E., \& Rhee, K. S. (1988). Influence of animal diet and muscle location on cholesterol content of beef and pork muscles. Meat Science, 23(1), 71-75. http://dx.doi.org/10.1016/0309-1740(88)900630. PMid:22055476.

Bridi, A. M., \& Silva, C. A. (2009). Avaliação da carne suína (1st ed.). Londrina: Midiograf.

Egea, M., Linares, M. B., Garrido, M. D., Madrid, J., \& Hernández, F. (2016). Feeding Iberian $\times$ Duroc cross pigs with crude glycerine: effects of diet and gender on carcass and meat quality. Meat Science, 111, 78-84. http://dx.doi.org/10.1016/j.meatsci.2015.08.008. PMid:26343013.

Faria, P. B., Cantarelli, V. S., Fialho, E. T., Pinto, A. M. B. G., Faria, J. H., Rocha, M. F. M., Guerreiro, M. C., \& Bressan, M. C. (2015). Lipid profile and cholesterol of pork with the use of glycerin in feeding. 
Arquivo Brasileiro de Medicina Veterinária e Zootecnia, 67(2), 535546. http://dx.doi.org/10.1590/1678-7112.

Ferreira, M. S. S., Garbossa, C. A. P., Oberlender, G., Pereira, L. J., Zangeronimo, M. G., Sousa, R. V., \& Cantarelli, V. S. (2013). Effect of ractopamine on lipid metabolism in vivo: a systematic review. Brazilian Archives of Biology and Technology, 56(1), 35-43. http:// dx.doi.org/10.1590/S1516-89132013000100005.

Folch, J., Lees, M., \& Stanley, G. H. S. (1957). A simple method for the isolation and purification of total lipids from animal tissues. The Journal of Biological Chemistry, 226(1), 497-509. http://dx.doi. org/10.1016/S0021-9258(18)64849-5. PMid:13428781.

Hanczakowska, E., Weglarzy, K., Szymczyk, B., \& Hanczakowski, P. (2010). Effect of adding crude or refined glycerol to pig diets on fattening performance, nutrient digestibility and carcass evaluation. Annals of Animal Science, 10(1), 67-73.

Hartman, L., \& Lago, R. C. (1973). Rapid preparation of fatty acids methyl esters from lipids. Laboratory Practice, 22(6), 475-476, passim. PMid:4727126.

Latimer, G. W. (2016). Official methods of analysis of AOAC International (20th ed.). Rockville: AOAC International.

Lee, D. P., Deonarine, A. S., Kienetz, M., Zhu, Q., Skrzypczak, M., Chan, M., \& Choy, P. C. (2001). A novel pathway for lipid biosynthesis: the direct acylation of glycerol. Journal of Lipid Research, 42(12), 1979-1986.

Li, C., Li, J., Jiang, W., Zhang, S., Shen, J., Wen, K., \& Wang, Z. (2015). Development and application of a gel-based immunoassay for the rapid screening of salbutamol and ractopamine residues in pork. Journal of Agricultural and Food Chemistry, 63(48), 10556-10561. http://dx.doi.org/10.1021/acs.jafc.5b04203. PMid:26595169.

Lindahl, G., Lundstrom, K., \& Tornberg, E. (2001). Contribution of pigment content, myoglobin forms and internal reflectance to the colour of pork loin and ham from pure breed pigs. Meat Science, 59(2), 141-151. http://dx.doi.org/10.1016/S0309-1740(01)00064-X. PMid:22062672.

Malau-Aduli, A. E. O., Siebert, B. D., Bottema, C. D. K., \& Pitchford, W. S. (1997). A comparison of the fatty acid composition of triacylglycerols in adipose tissue from Limousin and Jersey cattle. Australian Journal of Agricultural Research, 48(5), 715-722. http:// dx.doi.org/10.1071/A96083.

Melo, D. S., Faria, P. B., Cantarelli, V. S., Rocha, M. F. M., Pinto, A. M. B. G., \& Ramos, E. M. (2014). Qualidade da carne de suínos com uso de glicerina na alimentação. Arquivo Brasileiro de Medicina Veterinária e Zootecnia, 66(2), 583-592. http://dx.doi.org/10.1590/1678-41626204.

Mendoza, O. F., Ellis, M., McKeith, F. K., \& Gaines, A. M. (2010). Metabolizable energy content of refined glycerin and its effects on growth performance, and carcass and pork quality characteristics of finishing pigs. Journal of Animal Science, 88(12), 3887-3895. http:// dx.doi.org/10.2527/jas.2010-2873. PMid:20675606
Mills, S. E. (2002). Biological basis of the ractopamine response. Journal of Animal Science, 80(E2), 28-32. http://dx.doi.org/10.2527/ animalsci2002.80E-Suppl_2E28x.

Montell, E., Lerín, C., Newgard, C. B., \& Gómez-Foix, A. M. (2002). Effects of modulation of glycerol kinase expression on lipid and carbohydrate metabolism in human muscle cells. The Journal of Biological Chemistry, 277(4), 2682-2686. http://dx.doi.org/10.1074/ jbc.M107227200.

Muriel, E., Ruiz, J., Ventanas, J., Petrón, M. J., \& Antequera, T. (2004). Meat quality characteristics in different lines of Iberian pigs. Meat Science, 67(2), 299-307. http://dx.doi.org/10.1016/j.meatsci.2003.11.002. PMid:22061327.

Nakamura, M. T., \& Nara, T. Y. (2004). Structure, function, and dietary regulation of delta6, delta5, and delta9 desaturases. Annual Review of Nutrition, 24(1), 345-376. http://dx.doi.org/10.1146/annurev. nutr.24.121803.063211. PMid:15189125.

Parr, T., Jewell, K. K., Sensky, P. L., Brameld, J. M., Bardsley, R. G., \& Buttery, P. J. (2004). Expression of calpastatin isoforms in muscle and functionality of multiple calpastatin promoters. Archives of Biochemistry and Biophysics, 427(1), 8-15. http://dx.doi.org/10.1016/j. abb.2004.04.001. PMid:15178483.

Ramos, E. M., \& Gomide, L. A. M. (2012). Meat quality evaluation: fundamentals and methodologies. (2nd ed.). Minas Gerais: Federal University of Viçosa.

Rickard, J. W., Allee, G. L., Rincker, P. J., Gooding, J. P., Acheson, R., McKenna, D. R., \& Carr, S. N. (2017). Impact of ractopamine hydrochloride (Paylean') on performance of heavy finishing pigs using a 3-cut marketing strategy. Journal of Animal Science, 95(Suppl. 2), 98. http://dx.doi.org/10.2527/asasmw.2017.12.206.

Rostagno, H. S., Albino, L. F. T., Donzele, J. L., Gomes, P. C., De Oliveira, R. F. M., Lopes, D. C., Ferreira, A. S., \& Barreto, S. L. T. (2011). Brazilian tables for poultry and swine: composition of feedstuffs and nutritional requirements. (2nd ed.). Viçosa: Universidade Federal de Viçosa.

Silva, R. A. M., Pacheco, G. D., Agostini, P. S., Vinokurovas, S. L., Oliveira, E. R., Gavioli, D. F., Lozano, A. P., Bridi, A. M., \& Silva, C. A. (2013). Performance, carcass and meat quality of pigs fed diets with antioxidants and ractopamine. Semina: Ciências Agrárias, 34(6Suppl. 2), 39713982. http://dx.doi.org/10.5433/1679-0359.2013v34n6Supl2p3971.

Ulbricht, T. L., \& Southgate, D. A. (1991). Coronary heart disease: seven dietary factors. Lancet, 338(8773), 985-992. http://dx.doi. org/10.1016/0140-6736(91)91846-M. PMid:1681350.

Xiong, Y. L., Gower, M. J., Li, C., Elmore, C. A., Cromwell, G. L., \& Lindemann, M. D. (2006). Effect of dietary ractopamine on tenderness and postmortem protein degradation of pork muscle. Meat Science, 73(4), 600-604. http://dx.doi.org/10.1016/j.meatsci.2006.02.016. PMid:22062558. 